\section{THE FOREIGN-BORN INSANE}

A RACIAL STUDY OF THE PATIENTS ADMITTED TO THE INSANE DFPARTMENT OF THE PHILADELPHIA

GENERAL HOSPITAL IN TEN YEARS

$(1903-1912) *$

CHARLES W. BURR, M.D.

Professor of Mental Diseases, Cniversity of Pennsylvania, Depart-

I purpose briefly to discuss the question of the alien insane in the United States using for data the number of native and foreign-born who were admitted to the insane department of the Philadelphia General Hospital (Blockley) during the decade from 1903 to 1912 , inclusive. I should perhaps state that Blockley is the county hospital of Philadelphia, and that to its department for the insane are sent all indigent persons living in the city who become mentally ill, except a few who are admitted to the psychopathic.wards (separate from the insane department in a legal sense, though situated on the same piece of land), and later deported or transferred to other hospitals without passing through the insane department. The number received in the psychopathic wards and not later transferred to the insane department is not large enough to influence the percentage to any great extent; but as my statistics are made up from the admissions to the insane department alone, the number of foreign indigent insane in the city is a little larger than my figures indicate.

There are also in the city two semipublic hospitals for the insane which receive, for short periods, a few charity patients, few of whom, however, are foreigners. These institutions receive a somewhat larger number of patients who are able to pay for a short time, but who are finally sent either to the Philadelphia General Hospital or to a state institution. It is alleged, but $I$ personally know of only a few instances, that occasionally the relatives of immigrants who become ill soon after coming here send them to private institutions and support them long enough to make it practically impossible to deport them, unless they or their relatives desire it which they never do, and then have them transferred to a state institution or to Blockley. Though some of the foreign-born insane at B]ockley pay some board, the amount paid is so small and the number who pay so few that practically all may be regarded as indigent.

There are doubtless some mistakes in the statistics I present, but none of them leads to serious error in the conclusions drawn. Thus tifty patients are recorded as having been born in Poland, the recorder seemingly being of the opinion that Poland still flourishes as a political entity. The real explanation is that persons coming from either Russian or Austrian Poland, and less frequently those from German Poland, speak of themselves as Poles, and of course racially are such. In a few instances a man is credited to the country of his birth, though he does not belong to any of the races native to the country in which he happened to be born, and in a few others the mother was of one country and the father of another, in which case the paternal country is recorded. Some European countries, notably Russia, Austria and Germany, contain many races. In the hospital records only the country of birth is recorded, not the race. Hebrews are not recorded as such in the admission book, but only in the individual histories.

* Read at the meeting of the Phlladelphia Psychiatric Society, May 9,1913 .
They are here credited to the lands in which they were born. No attempt is made in this paper to distinguish the different races in any country, but all persons born in Germany are regarded as Germans, those born in Russia, Russians, and so on. All the errors of all kinds combined do not influence in any way the main conclusion that a startlingly large number, 44 per cent., of the indigent insane in the Philadelphia General Hospital are foreign-born. I have no statistics as to how many of them are politically aliens, that is, not citizens. No data are obtainable as to how long many of them: have been in this country; but quite a large number, especially among the Irish, English and Germans, have been here many years, while most of the Russians, Italians, Roumanians and Hungarians are recent acquisitions.

The figures on which the paper is based are as follows: The total population of Philadelphia in 1900 was $1,293,696$, and in $1910,1,549,008$. The foreignborn population in 1900 was 293,669 , and in 1910 it was 382,578 , of which 193,994 were males and 188.584 were females. The percentage of foreign-born in 1910 was 24.7 ; of white native-born, 69.8 , and of negroes 5.5. The negro population in 1900 was 62,613 ; in 1910 it was: males 39,431 and females 45,028 , making a total of 84,459 .

The total (sane and insane) foreign-born population in 1900 and 1910 is given in Table 1 (I have omitted countries from which no or only a small number of insane persons came). It is noteworthy that the number of Irish. English and Germans decreased in the ten years. The falling off in the number of Chinese is not hard to understand. All the figures were taken from the thirteenth census of the United States.

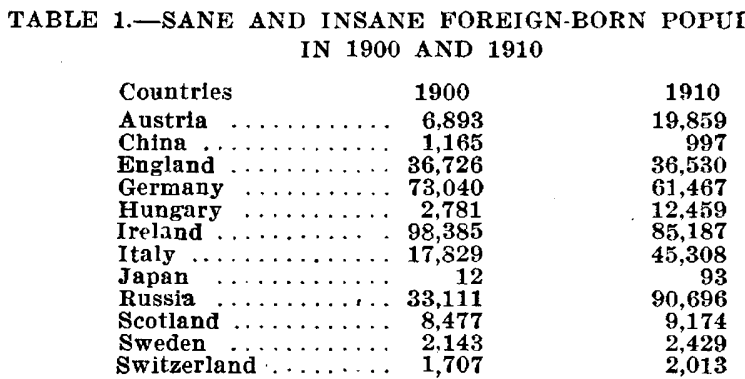

The statisties concerning the insane admitted to the hospital are as follows: During the years 1903 to 1912 , inclusive, there were admitted $4,89 \%$ males and 3,849 females, a total of 8,746 . Of these, 2,052 were foreign males and 1,837 foreign females, making a total of 3,889 foreign-born patients, which is 44.5 per cent.

The foreign-born insane (excluding countries sending only a few) came from the countries given in Table 2 .

TABLE 2.-THE FOREIGN-BORN INSANE

\begin{tabular}{|c|c|c|c|}
\hline Countries & Males & Females & Tota \\
\hline Austria & 111 & 75 & 186 \\
\hline England & 162 & 142 & 304 \\
\hline Germany & 429 & 315 & 744 \\
\hline Hungary & 58 & 50 & 108 \\
\hline Ireland & 499 & 741 & 1,240 \\
\hline Italy .. & 187 & 114 & 301 \\
\hline Poland* ${ }^{*}$. & 26 & 24 & 50 \\
\hline Roumania & 14 & 17 & 31 \\
\hline Russia & 306 & 251 & $\mathbf{5 5 7}$ \\
\hline Scotland & 30 & 42 & 72 \\
\hline Sweden $\ldots$ & 17 & 16 & $\mathbf{3 3}$ \\
\hline Switzerland & 23 & 12 & 35 \\
\hline
\end{tabular}

* This includes Austrian, Russian and German Poland. Many Poles are listed under the country in which they were born. The country of birth of the fifty is unknown. Most of them probably are Russians. 
The classification by color is given in Table 3 . All persons known to have negro blood are recorded as negroes, even though there may be a large admixture of white blood.

TABLE 3-CLASSIFICATION BY COLOR

\begin{tabular}{|c|c|c|c|}
\hline Races & Males & Females & Total \\
\hline Caucasians & 4,421 & 3,412 & 7,833 \\
\hline Negroes . & 457 & 437 & 894 \\
\hline Mongolfans & 19 & 0 & 19 \\
\hline
\end{tabular}

I have not given the table showing the number of patients from each foreign countrv admitted to the hospital each year of the decade, because it is not of enough value; but $I$ wish to make some quotations from it. The yearly figures would be of great value if we knew the yearly fluctuations in population, not during the last ten only, but throughout the last fifty years; but the only dependable statistics we have are those of the United States census, which is decennial. There is no way of finding out the racial character of the population year by vear. The tables of arrivals of immigrants by ship is of no value, because an unknown number immediately move to other places, and, on the other hand, an unknown number come here from other parts of this country.

It must be remembered that insanity occurs not only in recent immigrants, but also in foreigners who have lived here many years, though $I$ have been much impressed of late years by the number of recent young immigrants who become insane; but I have no data concerning the percentage. There is no close relation between the number of immigrants from any given country in any one year and the number of insane from the same country admitted to Blockley in that year. Some conclusions, however, can be drawn from the yearly tables. Thus there were 22 men and 13 women admitted from Russia in 1903; in 1912 there were 42 men and 28 women. 'The number varied in the intervening years, but on the whole the curve tended upward. There has been a pretty constant increase in the Russian immigration each year, and, since the death-rate is less than the number of new arrivals, there has undoubtedly been a yearly increase in the number of Russian residents, so that it is natural that the number of the insane should increase.

When we consider Italy we find that while the number of its people living in Philadelphia increased from 17,829 in 1900 to 45,308 in 1910 , the number of admissions to Blockley varied greatly from year to year, the greatest number being 44 in $190 \%$, and the smallest, 24 , in 1908 . In 1912 there were 41.

Fngland and Ireland, which represent an older laver of immigration than Russia or Italy, have pretty flat admission curves for the decade. In both instances the insanity curve will probably soon begin to fall, and then fall rapidly, unless, which is improbable, there should be a new wave of immigration from these countries.

Hungary, considering the small number of its people living here, makes a very bad showing-108 patients. Of course, however, in interpreting these figures it must be remembered there is no way of determining what percentage of the Hungarians who have lived in Philadelphia during the past ten years have become insane, because we do not know how many have lived here in that time; we only know the number for the first and tenth, but not the intervening years. I suspect, but am not sure, that quite a number of Hungarians living in other parts of the state, and indeed of the country, are sent to Pliladelphia by their friends as soon as they show signs of becoming ill. This, in a small degree, decreases the percentage of the insane Hungarians in other counties and states, and correspondingly increases the rate in Philadelphia. As the same data are lacking for all countries we can properly draw conclusions as to certain matters concerning all, and in doing so, Hungary does not stand well. Russia gives the greatest number of all foreigners, sane and insane, living in the city in 1910; Ireland ranks second, and Germany third. of the foreigners in the hospital, Ireland gives the greatest number, Germany is second and Russia third. I do not think that from this one can draw the conclusion that the Irish, under altered conditions of life in a foreign country, are more prone to insanity than the inhabitants of the Russian Empire. In the first place, the numbers we are dealing with are entirely too small to be of any use in the study of the racial frequency of disease, and in the second place, many Irish have lived here long enough to suffer from senile insanities, while the Russian is a newcomer, and the majority of immigrants from that country are still young.

The frequency of insanity in a race in its own home may be very different from that occurring in the same race in a foreign country, so that no conclusion can be drawn from my figures as to the relative susceptibility of different races in their home environment. The figures in Philadelphia are too small in any event, and even if we had accurate statistics covering the entire country, it would not be justifiable to draw conclusions as to racial susceptibility, except under the conditions in which the different races are now living. For example. I am quite sure, though I cannot prove it mathematically, that I have seen a large number of young Russian Jews in whom the exciting cause of disease was the total change in their environment: homesickness, inability to speak English, living in a large city instead of a small town or the country, the hurry of life and the intensity of work all act as exciting causes. Many of these persons, I believe, could, at home, have passed through life escaping all mental disease. It is, therefore, quite possible that the insanity-rate is higher among the Russian Jews here than in Russia. I am entirely incompetent to express an opinion as to whether or not the alleged persecution of Jews in Russia takes the place of the exciting causes of insanity existing here, and keeps the freauency of occurrence at the same level in both countries. Several races seem, however, to be mentally and emotionally much more adaptable to American life than the Russian Jew.

The important question for us as a nation is whether we should let things continue as they are or should do more than is being done to keep out the insane and to return to their native countries aliens who becnme insane. We are told by gentlemen who make political. speeches in parts of the country in which there is a large foreign voting element that our national digestion is so strong that no evil can come by keeping our doors wide open for everybody. We hear much about being a haven for the oppressed, ete. We are told by the pessimists that we are "going to smash anyway," so there is no use doing anything. We are told by the disciples of "the uplift" that if we only send everybody to school and have plenty of laws to lift everybody up all evil will disappear. 'Probably none of these statements is true. Whether we can digest the foreigners or not, there is no reason why we should nake our burden any heavier than we must. It is our duty to take care of the naturalized foreigner if he becomes unable to care for himself; it is his right as a citizen. 
That we owe such duty to the alien no one believes, save those persons who have become so modern as to berieve, and not only profess to believe, that it is our duty to relieve other people of their duty, a kind of morality which to the old-fashioned seems highly immoral and ultimately leading to degeneracy of the helped. If, however, an alien has been here for some years, has worked, and has in a sense become one of us, we ought, I presume, to care for him. To-day he cannot be deported if he has been here only a few years. Surely it would be better to deport all aliens who become insane within five years of their arrival, no matter what the cause.

I am told, whether correctly or not I do not know, that this would necessitate the abrogation of treaties with several countries; but if it be true, certainly we -who abrogated a treaty with Russia simply because she claimed the right of deciding what persons could pass her borders, a right which we ourselves claim and rigidly enforce when we want to, professedly on the highly sentimental ground that a certificate of American citizenship should open all doors-would be justified in abrogating treaties which compel us to take care of the mental wreckage properly belonging to other countries.

It is sometimes stated, but not proved, that since insanity is no more frequent among the foreigners than among the native-born we are no worse off by admitting and keeping them than if we refused to receive and expelled them. After all, it is said, healthy foreigners, by building up the country, pay for the upkeep of their insane. If it were not easily practicable largely to exclude the insane and degenerate, then of course it would be better to admit them than to prohibit all immigration. But that is not the question, because it is entirely possible to welcome the one while excluding the other. The fact still remains, no matter how much we may try to forget the inevitable effects, that in Philadelphia a foreign-born population of 24.7 per cent. supplies 44 per cent. of the indigent insane, and the same proportion approximately is found in all large asylums in all parts of the country to which immigrants go in large numbers.

1918 Spruce Street.

\section{A CASE OF MULTIPLE SEROSITIS AND REPORT OF NECROPSY}

WITH REMARKS ON TWO CASES, APPARENTLY EARLY INSTANCES OF THE SAME CONDITION

SOLOMON SOLIS COHEN, M.D.

Professor of Clinical Medicine, Jefferson Medical College; Physician to Jefferson Hospital and Philadelphia General Hospital AND

R. MAX GOEPP, M.D.

Professor of Clinical Medicine, Pbiladelphia Polyclinic; Assistant Professor of Clinical Medicine, Jefferson Medical College; Assistant Physician to Jefferson Hospital and Philadelphia. General Hospital PHILADELPHIA

Of the many names that have been proposed for the condition discussed in this report, we have selected "multiple serositis," because it is descriptive and at the same time sufficiently short and convenient for practical purposes. A. O. J. Kelly, whose contributions on this subject are among the best in American literature, pre-

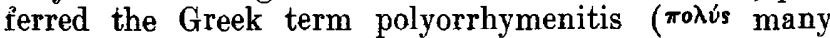
+ sposs serum $+\dot{v} \mu \eta^{\prime} \nu$, membrane). "Malignant inflam- mation of serous membranes," or "Concato's disease," is open to criticism on account of the conventional association of the word "malignant" with a cancerous process; while some of the other designations, particularly "general chronic perihepatitis," "sugar-iced liver" (Zuckergussleber-Curschmann), "pericarditic pseudocirrhosis of the liver" (Pick's disease) are not sufficiently comprehensive and lay too much stress on the hepatic and pericardial features, to the neglect of the other serous membranes.

A convenient working classification divides the cases into (1) those exhibiting chiefly perihepatitis (Curschmann's Zuckergussleber), in which the peritoneum as a whole is the primary seat of disease; and (2) cases beginning as a pericarditis, in which the process spreads later to the peritoneum and may or may not involve the covering of the liver (Pick's pericarditic pseudocirrhosis, adherent pericardium). Clinically it is not usually possible to determine which organ was the primary seat of disease. In the case here reported, the pleural and peritoneal cavities were both extensively involved and there was also adhesive pericarditis. The symptoms, however, were predominantly cardiac, during the entire course of the malady, which extended over three years, and although this was in part owing to degenerative cardiovascular changes not necessarily connected with the serous membrane inflammations, the case may be classified in the pericarditic group. The report of the case follows:

History.-J. G., an unmarried Irish blacksmith, aged 43, was admitted to the wards of the Philadelphia General Hospital, Oct. 10, 1912. The chief complaint of the patient on admis sion was shortness of breath, cough, and swelling of the legs and abdomen. The patient bore all the marks of an alcoholic and admitted having been a heavy drinker. He had had meas. les, mumps, whooping-cough and small-pox. Eleven years before admission he had had an attack of rheumatism. Gonorrhea had been contracted about fifteen years before admission, and syphilis at some earlier time. No information of importance in regard to the family history was obtained. During the past thirteen years the patient was treated in the Philadelphia General Hospital eight different times, but had not; prior to the last admission, come under our observation. The dates of admission and discharge, and the recorded diag noses, are as follows:

Jan. 5, 1904, to Feb. 1, 1904: Inflammation of penis and prepuce.

April 5, 1904, to April 11, 1904: Alcoholism.

Oet. 8, 1909, to Nov. 15, 1909: Pulmonary tuberculosis.

May 4, 1910, to June 28, 1910: Acute gastritis.

October 4, 1910, to June 26, 1911: Aortic regurgitation. mitral regurgitation; specific aortitis.

Sept. 8, 1911, to Sept. 27, 1911: Hepatic cirrhosis with ascites.

Oct. 9, 1911; to June 13, 1912: Aortic valvulitis; relative mitral regurgitation; cirrhosis.

Oet. 9, 1912, to Nov, 20, 1912: Multiple serositis and hypertrophie cardiac dilatation; aortic aneurysm or dilatation, relative aortic incompetence.

On admission to our service Oct. 9, 1912, the patient was orthopneic and markedly cyanotic. The abdomen was much distended with fluid, the legs and scrotum very edematous. The appetite was poor and the bowels were constipated. The patient complained of distress after eating, as if "all the food he took remained in the upper part of his belly." It seemed necessary to give prompt relief, and accordingly a trocar and cannula were inserted at the level of the umbilicus, about one inch to the right of the median line; the point for puncture being indicated by palpation which showed many adhesions and thickenings in the regions in which puncture is more usually made. One gallon of lemon-yellow and somewhat cloudy fluid was withdrawn. Microscopic examination of 